\title{
The Psychologist-Manager Journal
}

\author{
Editor \\ William D. Siegfried, Jr., Ph.D., Editor \\ The University of North Carolina, Charlotte
}

\section{EDITORIAL BOARD}

Judith E. N. Albino, Ph.D., University of Colorado Health Sciences and The Academy for Academic Leadership

Kenneth Ball, Ph.D., Ken Ball

Management Resources

Billie Blair, Ph.D., Leading and Learning, Inc.

John M. Cornwell, Ph.D., Rice University

Rosemary Hays-Thomas, Ph.D., The University of West Florida

Robert B. Kaiser, M.S., Kaplan DeVries Inc.

Thomas J. Kramer, Ph.D., The University of West Florida

Manuel London, Ph.D., State University of New York at Stony Brook

Rodney L. Lowman, Ph.D., Alliant International University

Edward J. Pavur, Jr., Ph.D., Management Service

\author{
Richard F. Ponton, Ph.D., Township of \\ Ocean, New Jersey \\ Linda M. Richardson, Ph.D., Mental \\ Health Systems, Inc. \\ George Yancey, Ph.D., Emporia State \\ University
}

\section{SPIM Officers and Board Members}

\author{
Co-Presidents: Billie Blair and \\ John Langhorne \\ Past President: Roger Cooper \\ Secretary: Connie Schroyer \\ Treasurer: Richard F. Ponton \\ Membership Chair: Dana Ackley \\ Directors: Rosemary Hayes-Thomas, \\ Robert J. Lee, John Martello, Allen L. \\ Parchem, John Reed, Mary C. Zahner
}

\begin{abstract}
PsycINFO/Psychological Abstracts; Cabells Directory of Publishing Opportunities in Management.

The Psychologist-Manager Journal (ISSN: 1088-7156) is published quarterly in March, June, September, and December by Taylor \& Francis Group, LLC., 325 Chestnut Street, Suite 800, Philadelphia, PA 19106. US Postmaster: Please send address changes to The Psychologist-Manager Journal, Taylor \& Francis, 325 Chestnut Street, Suite 800, Philadelphia, PA 19106.
\end{abstract}

Annual Subscription, Volume 14, 2011

Print ISSN - 1088-7156, Online ISSN - 1550-3461

Institutional subscribers: £290, US \$480, €384; Personal subscribers: £78, US \$129, €103. An institutional subscription to the print edition includes free access to the online edition for any number of concurrent users across a local area network.

Production and Advertising Office: 325 Chestnut Street, Suite 800, Philadelphia, PA 19106. Tel: 215625-8900, Fax: 215-625-8563. Production Editor: Jessica Hoffman.

Subscription offices: USA/North America: Taylor \& Francis Group, LLC., 325 Chestnut Street, Suite 800, Philadelphia, PA 19106. Tel: 215-625-8900; Fax: 215-625-2940; UK/Europe: Taylor \& Francis Customer Service, Sheepen Place, Colchester, Essex, CO3 3LP, United Kingdom. Tel: +44-(0)-20-70175544; Fax: +44-(0)-20-7017-5198. For a complete guide to Taylor \& Francis Group's journal and book publishing programs, visit our website: www.taylorandfrancis.com.

Copyright @ 2011 The Society of Psychologists in Management. All rights reserved. No part of this publication may be reproduced, stored, transmitted, or disseminated in any form or by any means without prior written permission from Taylor \& Francis Group, LLC. Taylor \& Francis Group, LLC. grants authorization for individuals to photocopy copyright material for private research use on the sole basis that requests for such use are referred directly to the requester's local Reproduction Rights Organization (RRO), such as the Copyright Clearance Center (www.copyright.com) in the USA or the Copyright Licensing Agency (www.cla.co.uk) in the UK. This authorization does not extend to any other kind of copying by any means, in any form, and for any purpose other than private research use. The publisher assumes no responsibility for any statements of fact or opinion expressed in the published papers. The appearance of advertising in this journal does not constitute an endorsement or approval by the publisher, the editor, or the editorial board of the quality or value of the product advertised or of the claims made for it by its manufacturer.

Permissions. For further information, please visit http://www.tandf.co.uk/journals/permissions.asp 